\title{
Prolonged low-dose dexamethasone treatment, in early gestation, does not alter blood pressure or renal function in adult sheep
}

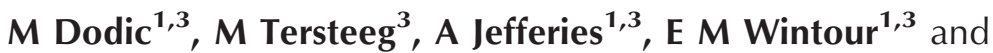 \\ K Moritz ${ }^{2,3}$ \\ ${ }^{1}$ Department of Physiology, Monash University, Clayton, Melbourne 3800, Victoria, Australia \\ ${ }^{2}$ Department of Anatomy and Cell Biology, Monash University, Clayton, Melbourne 3800, Victoria, Australia \\ ${ }^{3}$ Howard Florey Institute of Experimental Physiology and Medicine, University of Melbourne, Parkville 3052, Victoria, Australia \\ (Requests for offprints should be addressed to M Dodic, Email: miodrag.dodic@med.monash.edu.au)
}

\begin{abstract}
Low-dose dexamethasone treatment is used in pregnancies where the fetus is suspected to be at risk of congenital adrenal hyperplasia $(\mathrm{CAH})$. In order to see if such treatment had long-term effects, pregnant ewes were treated with dexamethasone $(20 \mu \mathrm{g} / \mathrm{kg}$ maternal body weight) or saline from 25 to 45 days of gestation and blood pressure and renal function studied in offspring at 2 years of age. There were 11 animals from dexamethasone treatment (six females and five males) and nine lambs from saline treatment (five females and four males). We aimed to study blood pressure and heart rate in the adult animals of both genders, and renal function only in the adult female animals.

In both females and males, blood pressure and heart rate were similar between the two groups of animals. The
\end{abstract}

excretion rates of sodium and potassium were similar between the two groups of animals. In addition, glomerular filtration rate was not different between the two groups of animals $(112 \pm 11 \mathrm{ml} / \mathrm{kg}$ per h (S.E.M.) in saline-treated females vs $112 \pm 10 \mathrm{ml} / \mathrm{kg}$ per $\mathrm{h}$ in dexamethasonetreated females). There were no differences in body weight or weights of the kidney and heart between the treatments in both females and males.

In conclusion, these results are reassuring for patients similarly exposed to prenatal dexamethasone treatment for $\mathrm{CAH}$, as in our animal model no evidence of altered renal function or predisposition to adult hypertension was found.

Journal of Endocrinology (2003) 179, 275-280

\section{Introduction}

Low-dose dexamethasone treatment $(20 \mu \mathrm{g} / \mathrm{kg}$ maternal body weight per day) is used to treat women suspected of carrying a fetus at risk for congenital adrenal hyperplasia $(\mathrm{CAH})$ in order to suppress overproduction of fetal androgens before and during the period of sexual differentiation (Forest et al. 1998, White \& Speiser 2000, New 2001). This treatment is known to prevent virilisation of the female embryo. The treatment usually starts at 5 weeks, $(\sim 12.5 \%$ gestation $)$ and ends, if amniocentesis proves the fetus to be male, or not carrying the genetic defect, by 12 weeks ( $\sim 30 \%$ gestation). However, as only one in eight fetuses is likely to be an affected female (CAH is an autosomal recessive disorder with a 50:50 male to female ratio), the other seven will receive this treatment unnecessarily and concern has been raised that these fetuses as adults may have adverse consequences (White \& Speiser 2000).

These concerns have arisen because of the several lines of evidence suggesting that excess prenatal glucocorticoids can lead to adult cardiovascular and metabolic disease (Seckl 2001, Dodic et al. 2002c). There is now very convincing epidemiological evidence that links inappropriately low birth-weight for gestational age and poor growth in the first postnatal year, with an increased risk for the development of hypertension, coronary heart disease, diabetes type 2 and dyslipidaemia in adult life (Osmond \& Barker 2000). There is evidence that exposure of the fetus to excess natural or synthetic glucocorticoids can decrease birth-weight and produce cardiovascular and metabolic disease in adult offspring (Robinson et al. 2000, Welberg $\&$ Seckl 2001). However, the effect of prenatal glucocorticoid treatment on birth-weight and adult hypertension is not exclusively associated (Dodic et al. 2002a,b).

Animal studies in which high doses of dexamethasone were given to the mother for various times during pregnancy have led to offspring with cardiovascular and metabolic disease (Dodic et al. 1998, Welberg \& Seckl 2001). Previous studies in our laboratory demonstrated that highdose dexamethasone treatment administered to pregnant ewes $(240 \mu \mathrm{g} / \mathrm{kg}$ maternal body weight per day), and thus 
their fetuses, for 2 days, early in pregnancy (26-28 days of gestation), has profound effects on adult cardiovascular function (Dodic et al. 1998, 1999, 2001b, 2002a). Also, this 2 day high-dose dexamethasone treatment causes significant changes in gene expression in the kidney, brain and hearts of twin ovine fetuses, killed at 130 days of gestation (Dodic et al. 2001a, Hantzis et al. 2001). In addition, several studies in rats have demonstrated high blood pressure associated with lower nephron number and altered renal function in an adult as a consequence of previous exposure to prenatal dexamethasone treatment (Celsi et al. 1998, Ortiz et al. 2001). In cases of intrauterine growth retardation, the kidney has been shown to be particularly susceptible to defects in organogenesis (Hinchliffe et al. 1992, Konje et al. 1996) and the smaller the kidney, the higher the cord-blood renin and angiotensin II levels (Kingdom et al. 1993, Konje et al. 1996). Interestingly, low nephron number, as a result of prenatal dexamethasone exposure, is not always associated with low renal weight (Ortiz et al. 2001, Seckl 2001).

Previously we have shown that the low-dose dexamethasone treatment, administered to the pregnant ewe between 25 and 45 days of gestation (term $\sim 150$ days), transiently affects adrenal growth and expression of the rate-limiting enzyme P450 scc (Moritz et al. 2002). Twin fetuses exposed to that treatment and studied late in gestation were symmetrically growth retarded and had altered glucocorticoid and mineralocorticoid receptor mRNA expression in the hippocampus (Moritz et al. 2002). However, by 2 months of age the offspring from the low-dose dexamethasone treatment were of normal body weight but had lower kidney weight (Moritz et al. 2002). This observation formed the basis of this follow-up study. More specifically, the concern was raised that hypertension may develop later in these animals, due to the possible impairment of their renal function. Therefore the aim of the current study was to determine whether prenatally administered low-dose dexamethasone treatment had any long-term effects on blood pressure and heart rate (HR) in the adult animals of both genders, and renal function in the adult female animals only.

\section{Methods}

Animals

All experiments were approved by the Animal Ethics Committee of the Howard Florey Institute in accordance with the National Health and Medical Research Council of Australia guidelines. Twenty pregnant Merino ewes weighing between 45 and $55 \mathrm{~kg}$ were used in this study. On day 22 or 23 of gestation, a silastic cannula (Dow Corning, Midland, MI, USA) $(0.76 \mathrm{~mm}$ i.d., $1.65 \mathrm{~mm}$ o.d.) was inserted into the maternal jugular vein under local anaesthesia (1 $\mathrm{ml} \mathrm{0.5 \%} \mathrm{Xylocaine;} \mathrm{Astra} \mathrm{Zeneca).}$ Between days 25 and 45 of gestation, ewes were infused with either isotonic saline $(0.19 \mathrm{ml} / \mathrm{h} ; n=9)$ or dexa- methasone $(20 \mu \mathrm{g} / \mathrm{kg}$ per day; $n=11)$. Days $25-45(17-$ $30 \%$ of gestation) were chosen as this period corresponds, in terms of kidney development, to weeks 5-12 of human development (Moritz \& Wintour 1999). After the treatment, ewes were returned to the farm to lamb.

At 1 year of age, in both male and female animals, a carotid arterial loop was surgically constructed. This cohort of females was not used in any other previous study. For the initial studies (blood pressure and renal function), female offspring remained intact (non-oophorectomised). Following the conclusion of the blood pressure and renal function experiments, females were oophorectomised at $\sim 2$ years of age and 4 weeks later further blood pressure measurements were made. As part of the previous studies, looking at blood pressure and hormonal responses to rubber-ring castration and tail docking, males were castrated at 2 months of age (Moritz et al. 2002, Peers et al. 2002). In wethers from a different cohort, we have shown that at 2 years of age, blood pressure is not affected by replacing testosterone for 3 weeks at normal physiological levels (Dodic et al. 2002a).

Construction of the carotid artery loop and oophorectomy were performed under general anaesthesia. General anaesthesia was induced with 5\% thiopentone sodium (Penthotal; Rhone Merieux, Athens, GA, USA) given via the jugular vein, and an endotracheal tube was inserted. Anaesthesia was maintained on an isoflurane anaesthetic (Isoflo inhalation anaesthetic; Abbott, Cronvilla, New South Wales, Australia), 15\% Isoflo/oxygen mixture (4:1 oxygen to air).

At the conclusion of all blood pressure and renal function experiments animals were killed with $100 \mathrm{mg} / \mathrm{kg}$ pentobarbitone sodium (Lethabarb; Arnolds, Reading, UK) and tissues collected.

\section{Blood pressure measurements}

In each animal, blood pressure and HR were measured, every $10 \mathrm{~min}$ for 3 days (Dodic et al. 1998, 1999, 2001b). Blood pressure and HR were measured via a Tygon cannula $(1.0 \mathrm{~mm}$ i.d., $1.5 \mathrm{~mm}$ o.d.) inserted approximately $10 \mathrm{~cm}$ proximally into the carotid loop and connected to a pressure transducer (TD XIII; Cobe, Colorado, CO, USA). The pressure was corrected to compensate for the height of the transducer above the level of the heart. The analog signal was digitally converted via a DT 301 Board Data Translation Device (Marlboro, Massachusetts, MA, USA) and blood pressure and HR data were recorded and collected at $100 \mathrm{~Hz}$ (HEM 3.1; Notocord, Kent Scientific Corp., Litchfield, CT, USA). HR was calculated by software from $\mathrm{dP} / \mathrm{dt}$ Max and took into account the peak of the $\mathrm{dP} / \mathrm{dt}$ curve during systole vs time.

\section{Renal function}

Renal function was assessed by measurement of glomerular filtration rate (GFR), urinary excretion rates of both 
sodium $\left(\mathrm{U}_{\mathrm{Na}} \mathrm{V}\right)$ and potassium $\left(\mathrm{U}_{\mathrm{K}} \mathrm{V}\right)$, fractional absorption of sodium $\left(\mathrm{F}_{\mathrm{Na}}\right)$ and potassium $\left(\mathrm{F}_{\mathrm{K}}\right)$ and free water clearance $\left(\mathrm{CH}_{2} \mathrm{O}\right)$. Following the completion of the 3 day blood pressure measurement, a cannula $(1.2 \mathrm{~mm}$ i.d., $1.7 \mathrm{~mm}$ o.d.) was inserted into a jugular vein under local anaesthetic (0.5\% Xylocaine). A Foley bladder catheter (size 12 French; Vitality Medical, Sandy, UT, USA) was inserted into the bladder for continuous collection of urine. The urinary bladder was emptied by a $1 \mathrm{~h}$ period of drainage, and a solution (12 ml) of $0.9 \% \mathrm{NaCl}(\mathrm{w} / \mathrm{v})$ containing $100 \mu \mathrm{Ci}{ }^{51} \mathrm{Cr}$-EDTA was infused via the jugular vein at $1.9 \mathrm{ml} / \mathrm{h}$ using a Braun pump (Melsungen, Hassen, Germany) for the duration of the experiment. The $3 \mathrm{~h}$ experimental protocol consisted of a $1 \mathrm{~h}$ equilibrium period and a $2 \mathrm{~h}$ measurement period. Urine was collected every $30 \mathrm{~min}$ throughout the experimental period, whilst an arterial blood sample $(3 \mathrm{ml})$ was collected mid-way through each collection period.

\section{Sample analysis}

Plasma and urinary solutes $(\mathrm{Na}, \mathrm{K}$, urea, creatinine and total protein) were measured on a Synchron CX5 system (Beckman, Fullerton, CA, USA). For the measurements of GFR, plasma and urine samples were analysed for ${ }^{51}$ Cr-EDTA on a Packard Cobra 5010 Gamma Counter (Packard Instrument Co., Downers Grove, IL, USA). Plasma and urine osmolalities were measured by freezing point depression using an Advanced Osmometer (Advanced Instruments, Norwood, Massachusetts, MA, USA).

\section{Statistics}

Values are reported as means \pm S.E.M. An unpaired $t$-test was used to compare the blood pressure and renal parameters of treatment groups. The statistical analysis was performed using Sigma Stat, version 2.03 (SPSS, Inc., Chicago, IL, USA).

\section{Results}

Infusions of saline and dexamethasone, over the 20 day period, did not cause any significant changes in the ionic composition of the maternal plasma (Moritz et al. 2002). In addition, as previously reported (Moritz et al. 2002), maternal plasma adrenocorticotrophic hormone concentration was significantly reduced by dexamethasone infusion measured on days 14 and 20, but not altered during saline infusion.

There was no difference in the maternal body weight at the time of the treatment $(51 \pm 2 \mathrm{~kg}$ in the salinetreated group, $n=9$, compared with $50 \pm 3 \mathrm{~kg}$ in the dexamethasone-treated group, $n=11$ ). There were 11 animals from dexamethasone treatment (six females,

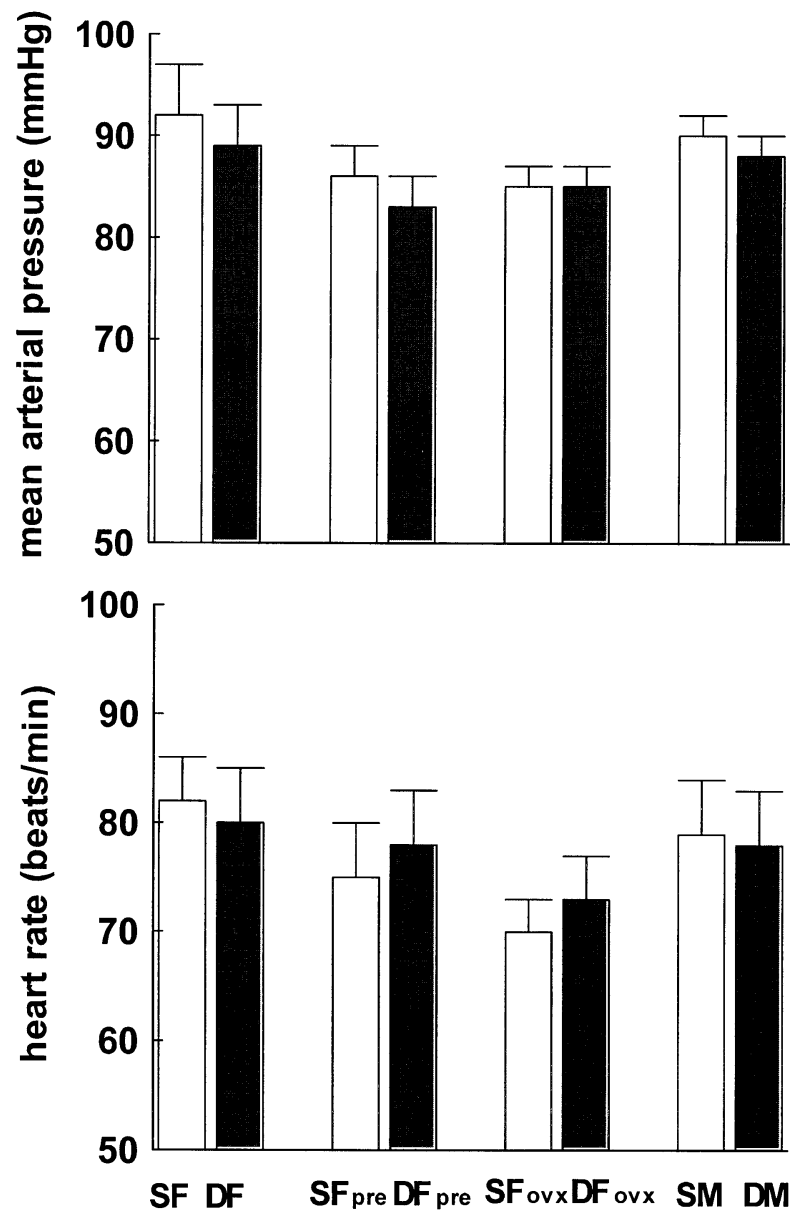

Figure 1 Mean arterial pressure and HR in offspring of sheep treated with either dexamethasone $(20 \mu \mathrm{g} / \mathrm{kg}$ maternal body weight) or saline, from 25 to 45 days of gestation. Blood pressure and HR were studied in female offspring for the first time at approximately 17 months of age (SF, $n=6$ and DF, $n=5)$ and also twice again at approximately 26 months of age, before the oophorectomy (SFpre, $n=6$ and DFpre, $n=5$ ) and 4 weeks following oophorectomy (SFovx, $n=6$ and DFovx, $n=5$ ). Blood pressure and HR in male offspring were studied at approximately 23 months of age (SM, $n=5$ and DM, $n=4)$. Basal mean arterial pressure was continuously monitored by computer at $10 \mathrm{~min}$ intervals for 3 days and represented as a mean value. Results shown as means \pm S.E.M.

Group DF and five males, Group DM) and nine lambs from saline treatment (five females, Group SF and four males, Group SM). Female offspring were born at a similar gestational age (Group SF $147 \pm 1$ day and Group DF $148 \pm 1$ day) and were of a similar birth-weights (Group SF $4 \cdot 0 \pm 0 \cdot 20 \mathrm{~kg}$ and Group DF $3 \cdot 6 \pm 0 \cdot 20 \mathrm{~kg}$ ). Male offspring were also born at a similar gestational age (Group SM $148 \pm 1$ day and Group DM $149 \pm 1$ day) and were of a similar birth-weights (Group SM $4 \cdot 1 \pm 0.3 \mathrm{~kg}$ and Group DM 3.8 $\pm 0 \cdot 3 \mathrm{~kg}$ ). 
Table 1 Plasma and urine concentrations of sodium, potassium, urea, creatinine and total protein and osmolality in female sheep treated with saline (Group SF) or dexamethasone ( $20 \mu \mathrm{g} / \mathrm{kg}$ per day; Group DF) between 25 and 45 days of gestation. Results are shown as means \pm S.E.M.

\begin{tabular}{|c|c|c|c|c|}
\hline & \multicolumn{2}{|l|}{ Plasma } & \multicolumn{2}{|l|}{ Urine } \\
\hline & Group SF $(n=5)$ & Group DF $(n=6)$ & Group SF $(n=5)$ & Group DF $(n=6)$ \\
\hline $\mathrm{Na}(\mathrm{mmol} / \mathrm{l})$ & $148 \pm 1$ & $150 \pm 1$ & $44 \pm 14$ & $72 \pm 27$ \\
\hline $\mathrm{K}(\mathrm{mmol} / \mathrm{l})$ & $4 \cdot 3 \pm 0 \cdot 1$ & $4 \cdot 3 \pm 0 \cdot 1$ & $188 \pm 81$ & $333 \pm 73$ \\
\hline Osmolality (mOsm/kg water) & $302 \pm 1$ & $308 \pm 2$ & $633 \pm 250$ & $1133 \pm 240$ \\
\hline Urea $(\mathrm{mmol} / \mathrm{l})$ & $6 \cdot 2 \pm 0 \cdot 3$ & $7 \cdot 1 \pm 0 \cdot 5$ & NA & NA \\
\hline Creatinine $(\mathrm{mmol} / \mathrm{l})$ & $0.077 \pm 0.003$ & $0 \cdot 078 \pm 0.003$ & $4 \cdot 2 \pm 1 \cdot 7$ & $6 \cdot 8 \pm 1 \cdot 4$ \\
\hline Total protein $(\mathrm{g} / \mathrm{l})$ & $67 \pm 2$ & $66 \pm 2$ & $0 \cdot 3 \pm 0 \cdot 1$ & $1 \cdot 1 \pm 0 \cdot 42$ \\
\hline
\end{tabular}

NA, urinary urea concentration not available.

\section{Blood pressure and HR measurements}

Blood pressure and HR measurements in the female offspring were performed for the first time at approximately 17 months of age (Group SF $17 \pm 1$ months and Group DF $16 \pm 2$ months) and also twice again at 26 months of age (Group SF $26 \pm 2$ months and Group DF $25 \pm 2$ months) before the oophorectomy and 4 weeks following the oophorectomy. At 17 months of age, the animals from Group SF weighed $39 \pm 3 \mathrm{~kg}$ during the experimental period, and that was not different from the animals in Group DF weighing $34 \pm 2 \mathrm{~kg}$. At 26 months of age, the animals from Group SF weighed $45 \pm 2 \mathrm{~kg}$ during the experimental period, and that was not different from the animals in Group DF weighing $44 \pm 2 \mathrm{~kg}$.

Blood pressure and HR measurements in the male offspring were performed only once, at approximately 23 months of age (Group SM $23 \pm 1$ months and Group DM $23 \pm 1$ months). At the time of the experimental period there were no differences in body weights between the two groups of animals (Group SM $42 \pm 2 \mathrm{~kg}$ vs Group DM $39 \pm 3 \mathrm{~kg}$ ).

In both females and males, blood pressure and HR were similar between the two groups of animals (Fig. 1). At 17 months of age, average mean arterial pressure was $92 \pm 5 \mathrm{mmHg}$ in Group SF, and $89 \pm 4 \mathrm{mmHg}$ in Group DF. HR in Group SF was $82 \pm 4$ beats/min, and $80 \pm 5$ beats/min in Group DF. In addition, oophorectomy did not have any impact on blood pressure or HR. Mean arterial pressure measured prior to oophorectomy was $86 \pm 1 \mathrm{mmHg}$ (Group SFpre) compared with $83 \pm 4$ mmHg measured 4 weeks after the oophorectomy was performed (Group SFovx). The oophorectomy did not affect blood pressure in Group DF, being $85 \pm 2 \mathrm{mmHg}$ before (Group DFpre) and $85 \pm 2 \mathrm{mmHg}$ following the oophorectomy (Group DFovx)).

In Group SM, mean arterial pressure was $90 \pm 1$ $\mathrm{mmHg}$, and $88 \pm 2 \mathrm{mmHg}$ in Group DM animals (Fig. 1). $\mathrm{HR}$ in the Group SM was $79 \pm 5$ beats $/ \mathrm{min}$ and $78 \pm 5$ beats/min in the Group DM animals (Fig. 1).

\section{Renal function}

Plasma and urine samples taken during the GFR experiments for measurement of ions, osmolality, total protein, urea and creatinine did not show any difference between Group SF and Group DF (Table 1). Urine flow rate was not different between the groups (Table 2). GFR, $\mathrm{U}_{\mathrm{Na}} \mathrm{V}$, $\mathrm{U}_{\mathrm{K}} \mathrm{V}, \mathrm{F}_{\mathrm{Na}}, \mathrm{F}_{\mathrm{K}}$ and $\mathrm{CH}_{2} \mathrm{O}$ were similar between the groups (Table 2).

\section{Post-mortem results}

As shown in Table 3, there were no differences in body weight or weights of the kidneys and hearts between the two treatments.

\section{Discussion}

In the current study we used an animal model that mimics the low-dose dexamethasone treatment used clinically in pregnancies suspected of being at risk for $\mathrm{CAH}$ and studied the possible long-term effects of such exposure. Although

Table 2 Glomerular filtration rate (GFR), urinary flow rate (UFR), urinary excretion rates of sodium $\left(\mathrm{U}_{\mathrm{Na}} \mathrm{V}\right)$ and potassium $\left(\mathrm{U}_{\mathrm{K}} \mathrm{V}\right)$, fractional reabsorption of sodium $\left(\mathrm{F}_{\mathrm{Na}}\right)$ and potassium $\left(\mathrm{F}_{\mathrm{K}}\right)$ and free water clearance $\left(\mathrm{CH}_{2} \mathrm{O}\right)$ in female sheep treated with saline (Group SF) or dexamethasone (20 $\mu \mathrm{g} / \mathrm{kg}$ per day; Group DF) between 25 and 45 days of gestation. Results were obtained on two different occasions and are shown as means \pm S.E.M.

GFR $(\mathrm{ml} / \mathrm{kg}$ per $\mathrm{h})$
UFR $(\mathrm{ml} / \mathrm{kg}$ per $\mathrm{h})$
$\bigcup_{\mathrm{Na}} \mathrm{V}(\mathrm{mmol} / \mathrm{h})$
$U_{\mathrm{K}} \mathrm{V}(\mathrm{mmol} / \mathrm{h})$
$\mathrm{F}_{\mathrm{Na}}(\%)$
$\mathrm{F}_{\mathrm{K}}(\%)$
$\mathrm{CH}_{2} \mathrm{O}(\mathrm{l} / \mathrm{kg}$ per $\mathrm{h})$

\begin{tabular}{c} 
Group SF $(n=5)$ \\
\hline $112 \pm 11$ \\
$3 \cdot 9 \pm 1$ \\
$6 \cdot 4 \pm 2 \cdot 60$ \\
$20 \cdot 3 \pm 4 \cdot 84$ \\
$98 \cdot 9 \pm 0 \cdot 54$ \\
$-16 \cdot 8 \pm 6 \cdot 68$ \\
$-0 \cdot 08 \pm 0 \cdot 050$
\end{tabular}


Table 3 Heart and kidney weights of adult female sheep treated with saline (Group SF) or dexamethasone $(20 \mu \mathrm{g} / \mathrm{kg}$ per day; Group DF) between 25 and 45 days of gestation. Results are shown as means \pm S.E.M. Right kidneys were perfused; therefore weights not presented

Body weight $(\mathrm{kg})$

Left kidney $(\mathrm{g})$

Left kidney/body weight $(\mathrm{g} / \mathrm{kg})$

Heart $(\mathrm{g})$

Heart/body weight $(\mathrm{g} / \mathrm{kg})$

\begin{tabular}{|c|c|}
\hline Group SF $(n=5)$ & Group DF $(n=6)$ \\
\hline $45 \pm 3$ & $42 \pm 2$ \\
\hline $57 \pm 2$ & $52 \pm 2$ \\
\hline $1 \cdot 3 \pm 0 \cdot 08$ & $1 \cdot 3 \pm 0 \cdot 10$ \\
\hline $188 \pm 17$ & $180 \pm 6$ \\
\hline $4 \cdot 2 \pm 0 \cdot 17$ & $4 \cdot 3 \pm 0 \cdot 10$ \\
\hline
\end{tabular}

the dose of dexamethasone administered to the pregnant ewe is the same as used in the clinical practice, it is difficult to determine if the level of the fetal exposure to dexamethasone is equal. There have been follow-up studies of human babies who carry the genetic defect (New 2001), but only few studies followed the individuals who did not have the defect, but were exposed to the low-dose dexamethasone treatment (Cabrera et al. 2001). Although a profound lack of clinical information exists on the long-term effects of prenatal dexamethasone treatment used for $\mathrm{CAH}$, it is partly due to the fact that the first group of humans treated has only reached adolescence (Trautman et al. 1995). Numerous studies, in different animal species, have demonstrated the link between prenatal exposure to excess glucocorticoids and altered cardiovascular and renal function in adulthood (Seckl 2001).

As mentioned earlier, we have an animal model, sheep, to study the possible long-term effects of low-dose dexamethasone treatment on offspring (Moritz et al. 2002). Using this animal model, we have shown previously that low-dose dexamethasone treatment transiently affects adrenal growth and expression of the rate-limiting enzyme P450 scc (Moritz et al. 2002). Interestingly, twin fetuses from such treatment, studied late in gestation, were symmetrically growth retarded. However, by 2 months of age offspring from the low-dose dexamethasone treatment were of normal growth, but had lower kidney weight (Moritz et al. 2002). Although we demonstrated that male offspring, exposed to low-dose dexamethasone treatment early in gestation, were normotensive, at 2 months of age, the concern was raised that hypertension may develop later in these animals, due to possible kidney impairment.

The results from this follow-up study suggest that prenatal low-dose dexamethasone treatment did not have any effect on blood pressure in both male and female offspring of sheep at 2 years of age. This is in contrast to the study in which high blood pressure was demonstrated for the first time in the 4-month-old sheep offspring exposed to high-dose dexamethasone between 26 and 28 days of gestation (Dodic et al. 1998). The difference in blood pressure outcomes between these two studies is probably due to the considerably lower dose of dexamethasone used in the current study ( $\sim 12$ times lower). In addition, in the former study, the effect of short prenatal dexamethasone exposure on blood pressure was shown in oophorectomised females and castrated males (Dodic et al. 1998, 2002a). We have shown previously that in castrated males chronic testosterone replacement does not affect blood pressure (Dodic et al. 2002a). In this study, we demonstrated that oophorectomy as well does not affect blood pressure in either control or dexamethasoneexposed groups of sheep. These results suggest that sex hormones do not play a significant role in maintenance of basal blood pressure in adult sheep nor modulate blood pressure changes induced by prenatal glucocorticoid exposure. In addition, in this particular cohort of animals blood pressure was not significantly different between males and females, as previously reported (Dodic et al. 2002a). However, a trend towards higher blood pressure in males was observed when blood pressure measurements were performed at the comparable ages.

The time of the dexamethasone treatment is an important period in renal development. In both human (weeks 5-12) and sheep (days 25-45) both meso- and metanephroi are present and at comparable stages of development (Moritz \& Wintour 1999). Recent evidence from animal studies suggests that there is a critical period, which corresponds to a very early, preglomerular stage of metanephric development, during which excess glucocorticoid may affect both final nephron number and predispose to hypertension (Moritz et al. 2003). Indeed, we have found recently that high-dose dexamethasone treatment, administered to pregnant ewes between 26 and 28 days of gestation, results in offspring with high blood pressure and fewer nephrons (Wintour et al. 2003). Nephron counting was not performed in the current cohort, as they had normal blood pressure and renal function.

In conclusion, these results are reassuring for those patients similarly exposed to prenatal dexamethasone treatment for $\mathrm{CAH}$, as in our animal model no evidence of an altered renal function or predisposition to adult hypertension was found.

\section{Funding}

This work was supported by a Block Grant form NH\&MRC (983001) and a grant in aid from Broken Hill Proprieties (BHP; Australia).

\section{References}

Cabrera MS, Vogiatzi MC \& New MI 2001 Long term outcome in adult males with classic congenital adrenal hyperplasia. Journal of Clinical Endocrinology and Metabolism 86 3070-3078. 
Celsi G, Kistner A, Aizman R, Eklof AC, Ceccatelli S, De Santiago A \& Jacobson S 1998 Prenatal dexamethasone causes oligonephronia, sodium retention, and higher blood pressure in the offspring. Pediatric Research 44 317-322.

Dodic M, May CN, Wintour EM \& Coghlan JP 1998 An early prenatal exposure to excess glucocorticoid leads to hypertensive offspring in sheep. Clinical Science 94 149-155.

Dodic M, Peers A, Coghlan J, May CN, Lumbers E, Yu Z \& Wintour EM 1999 Altered cardiovascular haemodynamics and baroreceptor-heart rate reflex in adult sheep after prenatal exposure to dexamethasone. Clinical Science 97 103-109.

Dodic M, Baird R, Hantzis V, Koukoulas I, Moritz K, Peers A \& Wintour EM 2001a Organs/systems potentially involved in one model of programmed hypertension in sheep. Clinical and Experimental Pharmacology and Physiology 28 306-311.

Dodic M, Samuel C, Moritz K, Wintour EM, Morgan J, Grigg L \& Wong J $2001 b$ Impaired cardiac functional reserve and left ventricular hypertrophy in adult sheep after prenatal dexamethasone exposure. Circulation Research 89 623-629.

Dodic M, Abouabtoun T, O'Connor A, Wintour EM \& Moritz K $2002 a$ Programming effects of short prenatal exposure to dexamethasone in sheep. Hypertension 40 729-734.

Dodic M, Hantzis V, Duncan J, Rees S, Koukoulas I, Johnson K, Wintour EM \& Moritz K $2002 b$ Programming effects of short prenatal exposure to cortisol. FASEB Journal 16 1017-1026.

Dodic M, Moritz K, Koukoulas I \& Wintour EM 2002c Programmed hypertension: kidney, brain or both? Trends in Endocrinology and Metabolism 13 403-408.

Forest MG, Morel T \& David M 1998 Prenatal treatment of congenital adrenal hyperplasia. Trends in Endocrinology and Metabolism 9 284-289.

Hantzis V, Albiston A, Matsacos D, Wintour EM, Peers A, Koukoulas I, Myles K, Moritz K \& Dodic M 2001 Ontogeny of mineralocorticoid and glucocorticoid receptors in the developing ovine kidney and the effect of early glucocorticoid treatment on their expression in the late gestation kidney. Kidney 61 405-413.

Hinchliffe SA, Lynch MR, Sargent PH, Howard CV \& van Vezzen D 1992 The effect of intrauterine growth retardation on the development of renal nephrons. British Journal of Obstetrics and Gynaecology 99 296-301.

Kingdom JCP, McQueen J, Connell JMC \& Whittle MJ 1993 Fetal angiotensin II levels and vascular (type I) angiotensin receptors in pregnancies complicated by intrauterine growth retardation. British Journal of Obstetrics and Gynaecology 100 476-482.

Konje SA, Bell SC, Morton JJ, de Charal R \& Taylor DJ 1996 Human kidney morphometry during gestation and relationship between birth weight, kidney morphometry and plasma active rennin concentration at birth. Clinical Science 91 169-175.

Moritz K \& Wintour EM 1999 Functional development of meso- and metanephros. Pediatric Nephrology 13 171-178.

Moritz K, Butkus A, Hantzis V, Peers A, Wintour EM \& Dodic M 2002 Prolonged low-dose dexamethasone, in early gestation, has no long-term deleterious effect on normal ovine fetus. Endocrinology 143 1159-1165.

Moritz K, Dodic M \& Wintour EM 2003 Kidney development and the fetal programming of adult disease. BioEssays 25 212-220.

New MI 2001 Prenatal treatment of congenital adrenal hyperplasia. The United States experience. Endocrinology and Metabolism Clinics of North America 30 1-13.

Ortiz LA, Quan A, Weinberg A \& Baum M 2001 Effect of prenatal dexamethasone on rat renal development. Kidney International $\mathbf{5 9}$ 1663-1669.

Osmond C \& Barker DJ 2000 Fetal, infant, and childhood growth are predictors of coronary heart disease, diabetes, and hypertension in adult men and women. Environmental Health Perspectives 108 545-553.

Peers A, Mellor DJ, Wintour EM \& Dodic M 2002 Blood pressure, heart rate and other acute responses to rubber-ring castration and tail docking of lambs. New Zealand Veterinary Journal 50 56-62.

Robinson JS, Moore VM, Owens JA \& McMillen IC 2000 Origins of fetal growth restriction. European Journal of Gynecology and Reproduction Biology 92 13-19.

Seckl JR 2001 Glucocorticoid programming of the fetus; adult phenotypes and molecular mechanisms. Molecular and Cellular Endocrinology 185 61-71.

Trautman PD, Meyer-Bahlburg HF, Postelnek J \& New MI 1995 Effects of early prenatal dexamethasone on the cognitive and behavioural development of young children: results of a pilot study. Psychoneuroendocrinology 20 439-449.

Welberg LAM \& Seckl JR 2001 Prenatal stress, glucocorticoids and the programming of the brain. Journal of Neuroendocrinology 13 113-128.

White PC \& Speiser PW 2000 Congenital adrenal hyperplasia. Endocrine Reviews 21 245-291.

Wintour EM, Moritz K, Johnson K, Ricardo S, Samuel C \& Dodic M 2003 Reduced nephron number in adult sheep, hypertensive as a result of prenatal glucocorticoid treatment. Journal of Physiology 549 929-935.

Received 12 May 2003

Accepted 24 July 2003 